\title{
Enhancing The Inherent Coping Mechanism of Teachers in The Course of Health and Security Crisis
}

\author{
Gabriel T. Galleposo \\ Guintolan Elementary School, Payao, Philippines
}

\begin{abstract}
There is a dearth of studies on why people, specifically teachers, can immediately cope with health and security crisis, and continue to live their lives as normally as those who have not experienced such events in their lives, hence, the necessity to conduct this study. It explored the factors that influenced their coping mechanisms through exploratory sequential mixed method, involving respondents from seven schools district of Zamboanga Sibugay Division and from one school district of Lanao del Sur. The qualitative data gathered from 10 respondents through face-to-face interview and focused group discussion arrived at the factors that influenced the inherent coping mechanisms, namely: family, faith, profession, alliance, self-reliance, and service. The quantitative data gathered from 131 respondents through a researcher-made survey instrument were subjected to Pearson coefficient of correlation, t-test, weighted mean, and stepwise regression. It is concluded that faith, family, alliance, and profession wield a significant influence in the coping mechanisms of the respondents. Experience, and training were also found to have a differentiating performance in coping from health and security crisis; and that success in coping from catastrophic situations depends greatly on these factors. This study further proposed a model which can be used as basis in designing mental, spiritual, emotional, and social health programs to enhance the inherent coping mechanisms of teachers.
\end{abstract}

Keywords: Health crisis, security crisis, moving automobile model, profession, training experience

\section{Introduction}

Coronavirus Disease 2019 (COVID-19) threatened public health on an unprecedented global scale. It affected, and continues to upset the delicate balance of people's lives. This health crisis was augmented by the recently devastating conflict between the Armed Forces of the Philippines and the Abu Sayyaf that started on July 6, 2020 which claimed several lives (Lopez, 2020).

This upheaval added nervousness to the teachers particularly in the municipalities of Alicia, Payao, Olutanga, Mabuhay and Talusan, RT Lim, and Tungawan since some of the members of Abu Sayyaf group who escaped from the retaliation of the government forces sought refuge there. Lopez (2020) added that as precautionary measure to safeguard the residents from being abducted and turned into human shield, the Municipal Mayor of Olutanga issued Executive Order No. 29, s. 2020 on September 5, 2020, mandating suspension of classes in all levels, restrictions in reporting to work and in crossing Locsico Bay from Guicam, Alicia to Hula-hula, Mabuhay and vice versa.

The cataclysm was heightened when operatives from the joint task forces raided a suspected hideout of the Dawlah Islamiya-Abu Sayyaf Group in Alicia on September 6, 2020 after authorities received and validated information about the presence of suspicious individuals at the village of Sitio Tubigsina in Barangay La Paz, Alicia (Casimiro, 2020). The turmoil lasted for several days, forcing teachers on the affected areas to work from home, adding fear, distress, and anxiety to their already disturbed lives, until it died down to a whisper and unspoken words, but the gnaws of being caught by either or both calamity is always seen in the eyes of the concerned residents (Malonzo, 2020).

\footnotetext{
* Corresponding author.

E-mail address: xxxx@xxxxxx.edu (Fullname of corresponding author)
} 
As the crisis happened, the researcher observed, watched, and wondered in awe how the affected teachers of Alicia, Payao, Olutanga, Mabuhay, Talusan, RT Lim, and Tungawan districts sustained psychosocial aspects of their lives, performing very satisfactorily their job like printing, distributing, and retrieving the modules while carrying out efficiently other related tasks.

The researcher have reasons to believe that, amidst the chaos that threatened their security, and the pandemic that endangered their health and of their families, something have kept them going and treading along the path of servanthood. This study, therefore, uncovered these elements to which the strengths of these teachers came from and attributed to, and provided explanations on their coping mechanisms that helped them sustain their psychosocial aspects on equilibrium, and perform their profession very satisfactorily, if not outstandingly; and proposed a model that enhances the inherent coping mechanisms of teachers.

This study is associated with several national and international studies. Like the study of Dubey, et al. (2020) which stated that nationwide lockdowns can produce acute panic, anxiety, obsessive behaviors, hoarding, paranoia, and depression, and post-traumatic stress disorder (PTSD) in the long run. They also reported that the patients had their own coping mechanisms described as inspiration. Their study further recommended that psychosocial preparedness by setting up mental organizations specific for this particular pandemic was certainly necessary. Pfefferbaum and North (2020) reported that patients found strengths to stand up against the virus from their families, friends and loved ones. Additionally, in her report to the United Nations, Damanik (2020) found that teachers possessed innate and inherent traits of coping mechanisms from stress, depression, and panic in times of crisis. These elements were anchored on their motivations from their lives that came in many forms, such as: family, loved ones, friends, colleagues, and their belief in the Creator.

In the same light, Cole, et al. (2013) found that those who were affected by environmental crisis preserved their mental health and psychosocial dimension due to the following elements, namely: proximity to the event, personal history, education levels, age and gender, optimism, history of psychiatric difficulties, and available support networks.

The study of Talidong \& Toquero (2020) on the teachers' reaction to pandemic revealed that because of their innate coping mechanisms, the participants were found to adhere with quarantine requirements and at the same time found purposeful activities in dealing with the anxiety caused by the suspension of school-related tasks and activities Moreover, Nicomedes, et al. (2020) found that the process of adjustment of Filipino front liners to the new work conditions as a consequence of this COVID-19 pandemic crisis involved awareness of self-worth and importance, facing with the situation squarely, realization and, positivism, and, above all, faith in God - all are innate coping mechanisms.

Additionally, since the crisis can last longer a time than expected, affected individuals are found to be cognizant of their inner strength to safeguard themselves from its unfavorable outcomes. Managing environmental stress through self-devised coping mechanisms was found to have a lasting and longer influence over the individual's capacity in facing those challenges. They demonstrate mental alertness in times of panic, shortened period of recuperation if afflicted by illness, and a positive reaction to unexpected situation (Lugtu, 2020).

The reviewed literatures identified several elements or factors that identified the innate coping mechanisms of individuals in times of crisis. These elements were used as the main substance in pursuing this research and in constructing a model that proposes mental, emotional, spiritual, and social enhancement.

\section{Methodology}

This study employed exploratory sequential mixed method design which is anchored on the philosophical assumption of pragmatic world view (Morgan, 2007).

\subsection{Study Sample}

This study involved 141 participants, 10 of whom were interviewed during the qualitative phase; $5(50 \%)$ were males, $5(50 \%)$ were females, the remaining 131; $44(33.6 \%)$ males, $87(66.4 \%)$ females, were the respondents in the quantitative phase, marital status is consist of $43(32.8 \%)$ single, $88(67.2 \%)$ married; average age is 38 ; religious makeup is $118(90.1 \%)$ Christian, 13 (9.9\%) Islam; position is composed of 96 (73.3\%) teaching, 35 (26.7\%) 
teaching-related; average years of experience is 20 years; educational attainment makeup is $119(90.8 \%)$ of the respondents had units in or had graduated from master's degree, $12(9.2 \%)$ had units in or had graduated from doctoral degree; average DRRM/PSSP training is division level.

\subsection{Data Collection}

The data underwent a three-phase process (Creswell, 2014). The first phase included two steps. The first step was the face-to-face interview of randomly selected participants. The second step was analyzing qualitative data obtained from the interviews conducted. The second phase was the construction of survey instrument based on the factors that emerged in the first phase. The instrument was subjected to Cronbach Alpha to test its reliability which showed a value of .811, meaning, the instrument was very reliable. The last phase was the administration of the instruments, and recording of the responses.

\subsection{Measures}

After the results were obtained, the same were subjected into the following statistical tools: Pearson's Correlation Coefficient, to test whether or not a significant relationship exists among variables and the emerging factors; $t$ test to test whether or not there exists a significant difference in the coping actions of the respondents when grouped according to their profile variables; weighted mean was used to establish the level of perceptions in each of the emerging factors; and stepwise regression to establish factors which contribute to the development of a model for mental, spiritual, social, and emotional enhancement program.

\section{Results and Discussions}

\subsection{Qualitative Phase}

The excerpts of the interview were thematically analyzed and resulted into 43 codes. The codes were subjected into thematic analysis once more and as a result, the 43 categories were reduced to 13 emerging factors as shown in Table 1 .

Table 1. Conceptual Categories and Factors

\begin{tabular}{|c|c|c|}
\hline \multicolumn{2}{|r|}{ Conceptual Categories } & Factors \\
\hline 1. & Having the determination to protect the family. & Family \\
\hline 2. & Having the need to show my family courage amidst trying times. & \\
\hline 3. & By asking God for his blessing before making final decisions. & Faith \\
\hline 4. & Having the belief that God takes control in everything. & \\
\hline 5 . & $\begin{array}{l}\text { Entering into certain consultations, when needed, to uphold the standards } \\
\text { of my job. }\end{array}$ & Profession \\
\hline 6. & $\begin{array}{l}\text { Performing the duties and responsibilities relative to my job even during } \\
\text { security and health crisis. }\end{array}$ & \\
\hline 7. & $\begin{array}{l}\text { Consulting concerned authorities before making decisions relating to crisis } \\
\text { management. }\end{array}$ & Alliance \\
\hline 8 . & $\begin{array}{l}\text { Communicating to superiors and other concerned authorities eminent } \\
\text { danger, and threat which may lead to a perplexing situation. }\end{array}$ & \\
\hline 9. & $\begin{array}{l}\text { Establishing a link with my lived experiences to the present condition to } \\
\text { arrive at a sound decision. }\end{array}$ & Self-reliance \\
\hline & Being accountable to my actions in coping with the crisis. & \\
\hline & Providing support to people who are affected by the crisis. & Service \\
\hline & Helping everyone access support services. & \\
\hline 13. & Providing support and services to the local authorities. & \\
\hline
\end{tabular}

Thus, the study yielded six emerging factors, namely: family, faith, profession, alliance, self-reliance, and service as attributes in successful and rapid coping with crisis. 


\subsection{Quantitative Phase}

The data revealed that the respondents had very high levels of perception in all of the emerging factors as evidenced by the weighted mean of each of the emerging factors shown in Table 2.

Table 2. Weighted mean of the emerging factors.

\begin{tabular}{lr}
\hline \multicolumn{1}{c}{ Emerging Factors } & Average Wtd. $\bar{x}$ \\
\hline Family & 4.95 \\
Profession & 4.61 \\
Alliance & 4.73 \\
Self-reliance & 4.66 \\
Faith & 5.00 \\
Service & 4.65 \\
\hline
\end{tabular}

The relationship between the emerging factors and the inherent coping mechanism was analyzed using Pearson $\mathrm{r}$, the result indicated a strong positive relationship of all the emerging factors that surfaced in the qualitative phase as shown in Table 3.

Table 3. Correlation Coefficients between Levels of Perceptions of Emerging Factors and Coping Mechanisms

\begin{tabular}{llccl}
\hline & \multicolumn{1}{c}{ Factors } & $r$-value & $p$-value* & \multicolumn{1}{c}{ Interpretation } \\
\hline 1. & Family & .289 & .001 & Significant \\
2. & Profession & .509 & .000 & Significant \\
3. & Alliance & .560 & .000 & Significant \\
4. & Self-reliance & .619 & .000 & Significant \\
5. & Faith & .257 & .003 & Significant \\
6. & Service & .545 & .000 & Significant \\
\hline
\end{tabular}

* - at 0.05 level of significance

The difference in performance in coping with health and security crisis when the respondents are grouped according to their profile variables was analyzed using t-test. The data revealed that the respondents did not significantly differ in coping with crisis situation when grouped according to marital status, age, sex, religion, present position, and educational attainment. However, when grouped according to years of experience, and DRRM/PSSP-related training, a significant difference was found as shown in Table 4.

Table 4. Significant Difference of Coping Mechanisms based on Profile Variables. (N=131)

\begin{tabular}{|c|c|c|c|c|}
\hline Variables & Group & $\begin{array}{l}\text { Mean } \\
(\bar{x})\end{array}$ & $p$-value* & $\begin{array}{c}\text { Verbal } \\
\text { Interpretation }\end{array}$ \\
\hline 1. Sex & $\begin{array}{l}\text { Male } \\
\text { Female }\end{array}$ & $\begin{array}{l}4.36 \\
4.39\end{array}$ & .842 & Not Significant \\
\hline 2. Marital Status & $\begin{array}{l}\text { Single } \\
\text { Married }\end{array}$ & $\begin{array}{l}4.42 \\
4.36\end{array}$ & .691 & Not Significant \\
\hline
\end{tabular}




\begin{tabular}{|c|c|c|c|c|c|}
\hline & Variables & Group & $\begin{array}{l}\text { Mean } \\
(\bar{x})\end{array}$ & $p$-value* & $\begin{array}{c}\text { Verbal } \\
\text { Interpretation }\end{array}$ \\
\hline 3. & Age & $\begin{array}{l}21-39 \\
40 \& \text { above }\end{array}$ & $\begin{array}{l}4.40 \\
4.39\end{array}$ & .945 & Not Significant \\
\hline 4. & Religion & $\begin{array}{l}\text { Christianity } \\
\text { Islam }\end{array}$ & $\begin{array}{l}4.35 \\
4.69\end{array}$ & .085 & Not Significant \\
\hline 5. & Present Position & $\begin{array}{l}\text { Teacher } \\
\text { School Head }\end{array}$ & $\begin{array}{l}4.29 \\
4.59\end{array}$ & .023 & Not Significant \\
\hline 6. & $\begin{array}{l}\text { Years of } \\
\text { Experience }\end{array}$ & $\begin{array}{l}0-15 \\
16 \& \text { above }\end{array}$ & $\begin{array}{l}4.38 \\
4.38\end{array}$ & .001 & Significant \\
\hline 7. & $\begin{array}{l}\text { Educational } \\
\text { Attainment }\end{array}$ & $\begin{array}{l}\text { Master's Degree } \\
\text { Doctorate Degree }\end{array}$ & $\begin{array}{l}4.38 \\
4.36\end{array}$ & .898 & Not Significant \\
\hline 8. & $\begin{array}{l}\text { DRRM/PSSP- } \\
\text { Related Training }\end{array}$ & $\begin{array}{l}\text { District-Division } \\
\text { Regional-International }\end{array}$ & $\begin{array}{l}4.35 \\
4.48\end{array}$ & .005 & Significant \\
\hline
\end{tabular}

\subsection{Proposed Model}

Regression analysis on the emerging factors yielded a model that showed a very high contribution in coping crisis situation. The summary of the this model is presented in Table 5 .

Table 5. Model Summary Table for the Emerging Factors (Dependent variable: Coping Mechanism)

\begin{tabular}{lcccc}
\hline \multicolumn{1}{c}{ Predictors } & $R^{2}$ & $d f$ & $F$ & $p$-value* \\
\hline $\begin{array}{l}\text { Family, Faith, Profession, and } \\
\text { Alliance }\end{array}$ & .788 & 4,128 & 106.77 & .000 \\
\hline$*$ - at 0.05 level of significance & & &
\end{tabular}

The overall model was significant at $F(4,128)=106.77, \mathrm{R}^{2}=.788, \mathrm{p}=000$. The coefficient value of each of the predictors variables in the model are shown in Table 6.

Table 6. Coefficient Table of the Model for Emerging Factors

\begin{tabular}{|c|c|c|}
\hline Predictors & $p$-value* & Verbal Interpretation \\
\hline Faith & .000 & Significant \\
\hline Family & .000 & Significant \\
\hline Alliance & .003 & Significant \\
\hline Profession & .007 & Significant \\
\hline
\end{tabular}

* - at 0.05 level of significance 
A stepwise regression analysis was also performed for the profile variables. The analysis yielded a model that showed a very high contribution in the teachers' coping mechanisms as presented in Table 7.

Table 7. Model Summary Table for the Profile Variables (Dependent variable: Coping Mechanism)

\begin{tabular}{rcccc}
\hline Predictors & $R^{2}$ & $d f$ & $F$ & $p$-value* \\
\hline Experience, and Training & .202 & 4,128 & 11.01 & .000
\end{tabular}

* - at 0.05 level of significance

The overall model was significant at $F(4,128)=11.01, \mathrm{R}^{2}=.202, \mathrm{p}=000$. The coefficient value of each of the predictors variables in the model are shown in Table 8.

Table 8. Coefficient Table of the Model for Profile Variables

\begin{tabular}{lcc}
\hline \multicolumn{1}{c}{ Predictors } & p-value* & Verbal Interpretation \\
\hline Experience & .001 & Significant \\
Training & .008 & Significant \\
\hline
\end{tabular}

* - at 0.05 level of significance

Moving automobile model. This model is adopted from the work of Baang (2010). It is found to be the most suitable model for this study as illustrated in Figure 1 and is modified to take into account the predictors identified in the two regression models.

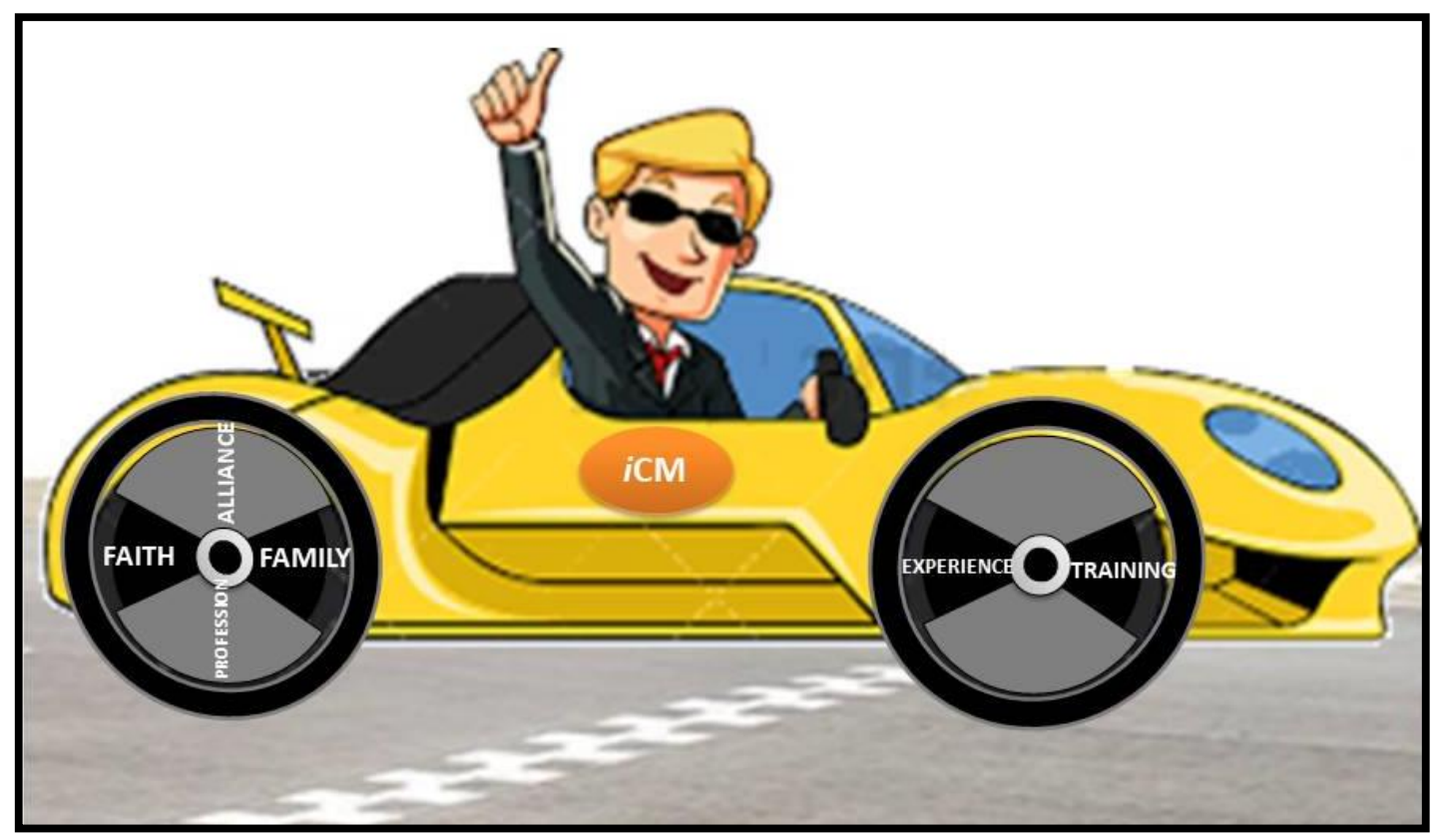

Fig. 1. The Modified "Moving Automobile Model"

Source: https://www.123rf.com/photo_50969571_stock-vector-cartoon-illustration-of-a-man-driving-a-sports-car.html 
Figure 1 shows the teacher onboard an automobile that represents inherent coping mechanisms. The automobile is supported by two sets of tires. The first set of tires represents the regression model on the emerging factors, namely: faith, family, alliance and, profession; while the second set of tires represents the regression model on the profile variables, namely: training, and experience. The finish-line represents the health and security crisis that the teacher overcomes.

\section{Discussions}

This study revealed six emergent factors that contribute to coping health and security crisis. Family pertains to the love, responsibility, and devotion of the respondents towards them. Faith is the respondents' steadfast belief on God's divine providence. Profession points out to the respondents' commitment and dedication to perform their duties and responsibilities as teachers. Alliance pertains to their relationship among community members. Self-reliance relates to the respondents' ability to do things and make decisions based on their knowledge and experience. Service is the respondents' effort in providing support services to their workplace and in the community.

Result of the t-test showed that respondents did not significantly differ in coping with crisis situation when grouped according to marital status, age, sex, religion, present position, and educational attainment.

However, when the respondents were grouped according to years of experience, those who were in the service for 16 and above can manage crisis facilely compared to those who were new in the service. Additionally, when grouped according to DRRM/PSSP-related training, those who attended regional, national, and international training can manage crisis straightforwardly as compared to those who attended district, and division training only.

The stepwise regression analysis on the emerging factors showed a very high $\mathrm{R}^{2}$ value of .788 which means that, taken as a set, the predictors Family, Faith, Profession, and Alliance account for $78.80 \%$ of the variance in the inherent coping mechanisms of teachers.

The stepwise regression analysis on the profile variables yielded an $\mathrm{R}^{2}$ value of .202 which means that, taken as a set, the predictors experience, and training account for $20.20 \%$ of the variance in the teachers' coping mechanisms in time to health and security crisis.

The regression analyses show that when the model of emerging factors, $\mathrm{R}^{2}=78.80 \%$ and the model of profile variables, $\mathrm{R}^{2}=20.20 \%$ are combined, they yielded $99 \%$ of the outcome variable, which means that $99 \%$ of the teachers' coping mechanisms in time of health and security crisis can be explained by faith which pertains to their strength drawn from belief and trust in God, by their love and devotion to their family, by their alliance with colleagues and authorities, by their commitment and dedication to their profession, by their lived experiences and public servants, and through their acquired skills and abilities in facing health and security crisis from training.

The moving automobile model The model is anchored on the goal-setting theory of Locke and Latham (1990) which hypothesized that individuals set challenging but attainable goals which are specific and measurable, and that the concerned individual must commit to the set goals to put sufficient effort towards reaching them. By expanding goalsetting theory, Abraham Maslow's (1943) hierarchy of needs theory comes in, particularly security and safety needs, and self-actualization.

Additionally, McClelland's (1961) achievement motivation theory is also used as another cornerstone of this model as it proposes that the needs or motives for achievement, affiliation, and power are influenced by either internal drivers or extrinsic factors. Internal drivers, in the context of this study, pertain to the actions of teachers that trigger their desires which emanate from the psychological, spiritual, and emotional competence in coping with the crisis. The external factors may come from their environment, and socialization influences as a result of their daily interactions with other members of the society.

\section{Conclusion}

The success in facing threatening circumstances and in coping with health and security crisis has its causal ascription to training and experience; to the love, responsibility and devotion to one's family; to the steadfast belief on God's divine providence characterized by one's faith; to the commitment and dedication in one's profession; to a well- 
founded alliance among colleagues and community members; in making well-informed decisions based on knowledge and experience; and, to one's involvement in providing support services to the workplace and the community; all of which can be enhanced using the model that this study proposes.

Based on the findings and the conclusion formulated from the insights (qualitative phase) and from the responses (quantitative phase) of the participants, as well as the personal points of view of the proponent experienced during the conduct of this study, the following are recommended to enhance the inherent coping mechanisms of teachers:

For the teachers:

(1) Be dynamic and prepared to face any challenging situation. This can be achieved by attending DRRM/PSSPrelated training.

(2) Be active. Learn from your lived experiences and from the experiences of other people.

(3) Value your family, and profession. They can serve as your staff as you tread along the path of servanthood.

(4) Establish and preserve well-grounded connection with the people in the community. They are your helping hands in times of crisis, and your inspiration in living life uprightly.

(5) Trust your self. Whenever you reach a point in making decisions, believe that your wisdom is brought into being by your knowledge and experience; and that you are not a product of random cosmic coalition of matters, but destined to live a life with purpose and meaning.

For Department of Education and other Government Officials

(1) As it is one of your responsibilities to protect and to promote the welfare of teachers, keeping them at the edge of their mental, emotional, social, physical, and spiritual dimensions is imperative; and this can be achieved through designing a program that can enhance their coping mechanisms.

(2) The proposed model can serve as vehicle in designing enhancement program inasmuch as their coping mechanisms are concerned.

For other researchers

(1) This study, although relevant only to coping with health and security crisis, could lead other scholars to further their understanding on the coping mechanisms of individuals in all kinds of catastrophic events.

(2) It can be replicated to prove or disprove the findings, thus, an avenue for a scholarly discussion and deliberation.

\section{References}

Capulso, L. B. (2020) Braving the K-12 Education in the Philippines amidst the COVID-19 pandemic. K12Digest. https://www.k12digest.com/braving-the-k-12-education-in-the-philippines-amidst-the-covid-19-pandemic/

Casimiro, Q. (2020, September 8). Suspected Abu Sayyaf hideout stormed in Zamboanga Sibugay. Patrol.PH. https://news.abs-cbn.com/news/09/08/20/suspected-abu-sayyaf-hideout-stormed-in-zamboanga-sibugay

Cole, R., Hayes, B., Jones, D. and Shah, S. (2013). Coping strategies used by school staff after a Crisis: A research note. Journal of Loss \& Trauma. 18 (5), 472-481. https:// 10.1080/15325024.2012.719335

Creswell, J. (2014). Research design : Qualitative, quantitative, and mixed methods approaches $4^{\text {th }}$ Ed. SAGE Publications, Inc.

Damanik, P. (2020, April 22). Ensuring psychosocial wellbeing of teachers and students in Indonesia. UNVolunteer Journal. April 22, 2020. https://www.unv.org/Success-stories/Ensuring-psychosocial-wellbeing-teachers-andstudents-Indonesia

Department of Education. (2020). DepEd Memorandum No. 042. Guidelines for the remainder of School Year 20192020 in light of COVID-19 measures. https://www.deped.gov.ph/wp-content/uploads/ 2020/03/DM_s2020_042-2.pdf 
Department of Education. (2020). DepEd Memorandum No. 043. Guidelines on the alternative work arrangements in the Department of Education in light of the COVID-19 stringent social distancing measures. https://www.deped.gov.ph/2020/03/15/march-15-2020-dm-043-s-2020- guidelines-on-the-alternative-workarrangements-in-the-department-of- education-in-light-of-the-covid-19-stringent-social-distancing-measures/

Dubey, A., Biswas, P., Ghosh, R., Chatterjee, S., Dubey, M., Lahiri, D., and Lavieh, C. (2020). Psychosocial impact of COVID-19. Diabetes \& Metabolic Syndrome: Clinical Research \& Reviews. 14(5): 779-788. https://doi.org/10.1016/j.dsx.2020.05.035

Lopez, V. (2020, July 8). Duterte slams 'lawless elements' for disrupting public order amid COVID-19 pandemic. GMA News Online. https://www.msn.com/en-ph/news/national/duterte-slams-lawless-elements-for-disruptingpublic-order-amid-covid-19-pandemic/ar-BB16HCc7

Lugtu, R. C., Jr. (2020, April 16). Coping strategies in times of crisis. The Manila Times. https://www.manilatimes.net/2020/04/16/business/columnists-business/coping-strategies-in-times-ofcrisis/714587/

MacIntyre, P. D., Gregersen, T., and Mercerc, S. (2020) Language teachers' coping strategies during the Covid-19 conversion to online teaching: Correlations with stress, wellbeing and negative emotions. System, 94. https://doi.org/10.1016/j.system.2020.102352

Malonzo, A. P. (2020, September 9). 5 Abu Sayyaf members killed in Zamboanga Sibugay clash. SunStar Zamboanga. https://www.sunstar.com.ph/article/1869655/ Zamboanga/Local-News/5-Abu-Sayyaf-members-killed-inZambo-clash

Morgan, D. (2007). Paradigms lost and pragmatism regained: Methodological implications of combining qualitative and quantitative methods. Journal of Mixed Methods Research, 1(1), 48-76. https://doi.org/10.1177/2345678906292462

Nicomedes, C. J., Avila, R. M., Arpia, H. M. (2020). The lived experiences of Filipino front liners during COVID-19 outbreak. https://doi.org/10.13140/RG.2.2.21221.35046/1

Pfefferbaum, B., and North, C. (2020). Mental health and the Covid-19 pandemic. The New England Journal of Medicine. (383) 510-512. https://doi.org/10.1056/NEJMp2008017

Republic Act No.11469 (2020). Bayanihan to heal as one act. http://legacy.senate.gov.ph/Bayanihan-to-Heal-as-OneAct-RA- 11469.pdf

Singh, R. (2020). COVID-19: A Complete Guide for Safety, symptoms, treatments, of Corona: South Carolina Department of Health and Environmental Control.

Strauss, A. (2001). Qualitative analysis for social scientists. Cambridge University Press. https://www.academia.edu/7430069/Anselm_L._Strauss_Qualitative__Analysis_for_Social_Scientists_1987

Talidong, K. J., and Toquero, C. D. (2020). Philippine teachers' practices to deal with anxiety amid COVID-19. Journal of Loss and Trauma.(25) 6-7, https://doi.org/10.1080/15325024.2020.1759225

World Health Organization Timeline - COVID-19. Retrieved October 24, 2020, from https://www.who.int/news/item/27-04-2020-who-timeline---covid-19

World Health Organization. (2020). Mental health and psychosocial considerations during the COVID-19 outbreak. In WHO. Retrieved October 24, 2020 from https://www.who.int/docs/default-source/coronaviruse/mental-healthconsiderations.pdf?sfvrsn=6d3578af_2 